\title{
Landslide Susceptibility Assessment based on Information Value Model in Amzaz Watershed in Northern Morocco
}

\author{
Évaluation de la sensibilité aux glissements de terrain basée \\ sur un Modèle de Valeur de L'information dans le bassin \\ versant de l'Oued Amzaz au nord du Maroc
}

\author{
Abdelhak El-fengour, University Ibn Tofail, Kenitra. Morocco/University of Castilla-La Mancha, Spain, \\ abdelhak.elfengour@uit.ac.ma \\ (1) https://orcid.org/0000-0002-4407-5245 \\ Carlos Bateira, Riskam, CEG, Universidade de Lisboa/Faculdade de Letras, Universidade do Porto, \\ Portugal, carlosbateira@gmail.com \\ (1) https://orcid.org/0000-0002-5039-6053 \\ Hanifa El motaki, University Ibn Tofail, Kenitra. Morocco/University of Santiago de Compostela Spain, \\ hanifa.elmotaki@uit.ac.ma \\ (1) https://orcid.org/0000-0003-0281-5310 \\ J. Horacio García, University of Santiago de Compostela, Spain, horacio.garcia@usc.es \\ (1) https://orcid.org/0000-0002-3116-015X
}

\begin{abstract}
This paper aims to identify potential areas of landslides in the Amzaz watershed in northern Morocco with its precarious environmental balance using the Information Value (IV) Model. Van Westen (1994) defines bivariate methods as a modified form of the quantitative map combination with the exception that weightings are assigned based upon the statistical relationship between past landslides and various factor maps, individual factor maps (independent variable). A set of factor maps were overlaid with a landslide map (dependent variable) to create cross-tabulations for each one and class. The landslide inventory is used to result in the susceptibility maps for better mitigation of the risks and losses related to this phenomenon. The results demonstrated that the percentage of rotational landslides varies between 8.79 and $30.08 \%$, and between 9.79 and $23.36 \%$ for translational slides susceptibility in the Amzaz watershed.
\end{abstract}

Keywords: Information Value Model, Landslides, Amzaz watershed, Rif, Morocco.

Résumé: Cet article vise à identifier les zones potentielles de glissements de terrain dans le bassin versant de l'Oued Amzaz, au nord du Maroc, dont l'équilibre environnemental est précaire, en utilisant le modèle de la valeur de l'information (IV). Van Westen (1994) définit les méthodes bivariées comme une forme modifiée de la combinaison de cartes quantitatives, à l'exception du fait que des pondérations sont attribuées en fonction de la relation statistique entre les glissements de terrain passés et les différentes cartes de facteurs, les cartes de facteurs individuels (variable indépendante). Un ensemble de cartes factorielles a été superposé à une carte des glissements de terrain (variable dépendante) afin de créer des tableaux croisés pour chacune d'entre elles et pour chaque classe. L'inventaire des glissements de terrain est utilisé pour établir les cartes de susceptibilité afin de mieux atténuer les risques et les pertes liés à ce phénomène. Les résultats ont montré que le pourcentage de glissements de terrain rotationnels varie entre 8,79 et $30,08 \%$, et entre 9,79 et $23,36 \%$ pour la susceptibilité aux glissements translationnels dans le bassin versant de l'Oued Amzaz.

Mots-clés: Modèle de Valeur de l'information, Glissements de terrain, Bassin versant de l'Oued Amzaz, Rif, Maroc. 


\section{Introduction}

Under the assumption that "the past and present are the keys to the feature" (Soeters and Westen, 1996), the statistical analysis uses a quantitative relationship between past landslides and the factors of the condition that led indirectly to the future landslides prediction with similar environmental conditions. This indirect, quantitative method provides a spatial probability for landslides occurrence. Statistical analyses are well known for providing more quantitative analysis of slope instability and are capable of examining the ability of various effects of each factor on one basis. Statistical analysis of slope movement can integrate both bivariate and multivariate methods. As an example, for multivariate methods, there is Support Vector Machine regression (SVMs), Logistic Regression (LR), and Decision Trees (DTs). While we can indicate these examples for bivariate methods, Frequency Ratio (FR), Weight of Evidence (WOE) and statistical Index (SI) and Informative Value (IV) (Yin and Yan, 1988). This paper aims to focus on the bivariate informative value model for landslides susceptibility assessment.

\section{Study area}

Amzaz valley sub-watershed is located in the Central Rif mountains in northern Morocco. It is a part of Ouerrha wadi watershed (Figure 1). Is limited from the NE and SE by the sub-watershed.

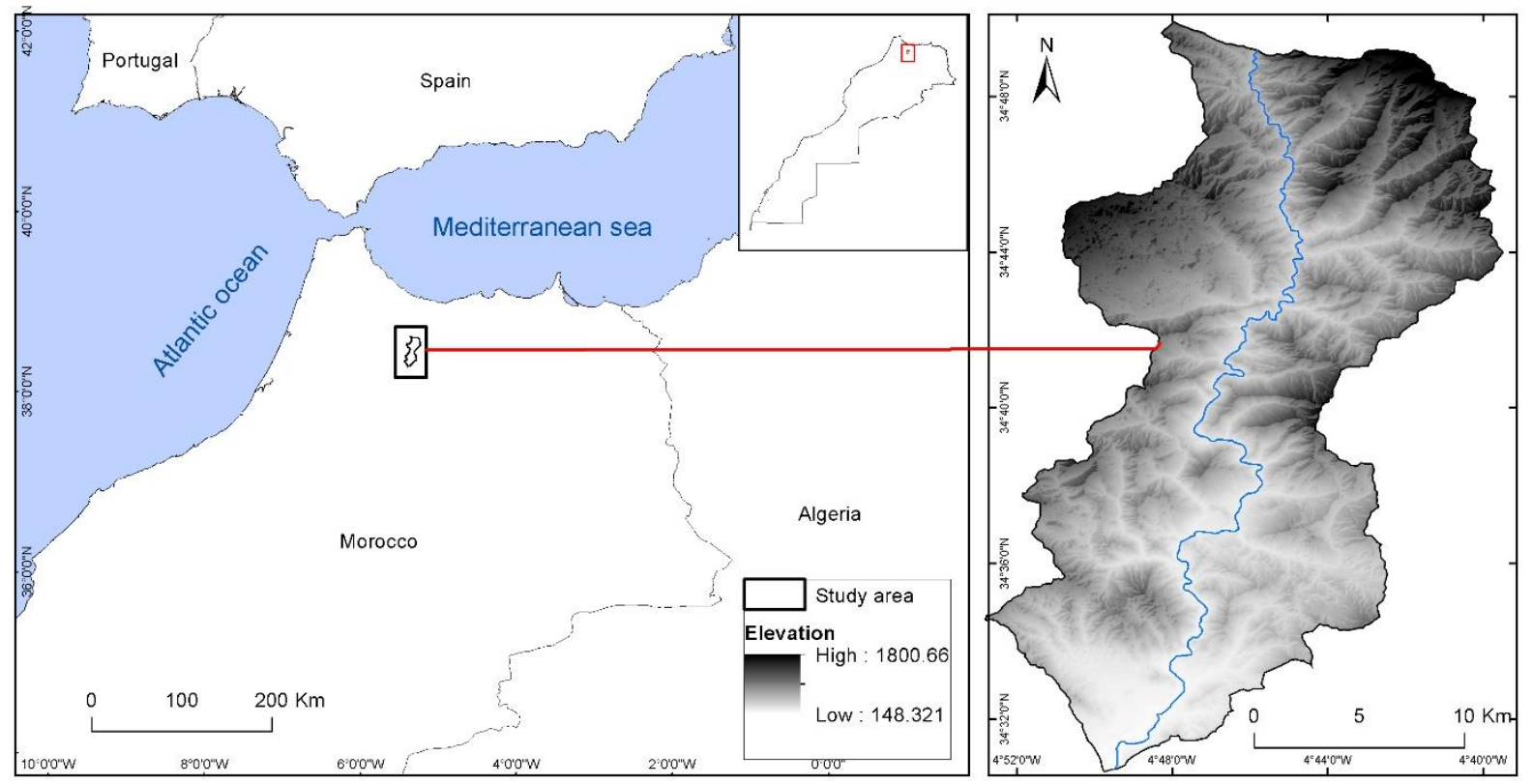

Figure 1: Geographical placement of Amzaz watershed.

Sahla, from the West by Aoulai valley sub-watershed. In the south part, it opened directly into the Ouerrha Wadi. Its boundaries were defined by ridgelines in the total area of $384 \mathrm{Km}^{2}$, this area was chosen for its geological and geomorphological characterization. 


\section{Materials and Methods}

The statistical analysis of slope movement using bivariate and multivariate methods is widely applied and provides more quantitative analysis of slope instability that can examine the various effects of different factors on an individual basis. As an example, for multivariate methods, there are SVMs (Support Vector Machine regression), LR (Logistic Regression), and DTs (Decision Trees). While we can indicate these examples for bivariate methods, FR (Frequency Ratio), WOE (Weight of Evidence), and SI (Index) IV (Informative Value). (Yin and Yan, 1988).

This study focuses on the bivariate informative value, which was chosen for landslides susceptibility assessment, by following numerous steps (Figure 2).

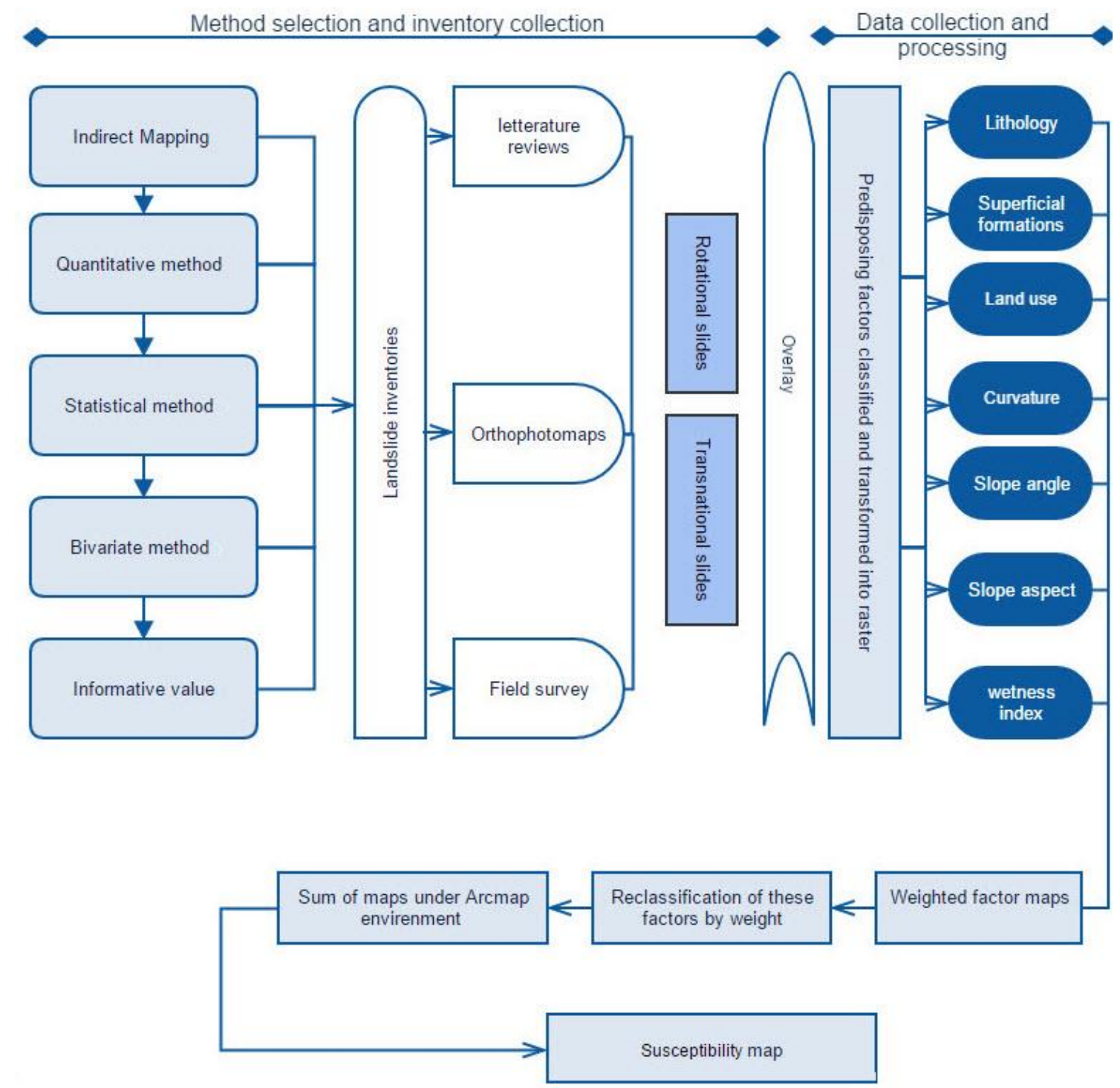

Figure 2: Workflow overview of IV method. 


\subsection{Informative Value Method}

The IVM estimates the influence of each conditioning factor on mass wasting and it can differentiate between more and less impacted within a relevant layer. The method was originally proposed by (Yin and Yan, 1988) expressed as (Equation 1).

$$
\mathrm{Ii}=\log \frac{\mathrm{Si} / \mathrm{Ni}}{\mathrm{S} / \mathrm{N}} \quad \text { Equation } 1
$$

Where,

- Si is the area with landslides belonging to the modeling group and the presence of variable $\mathrm{Xi}$.

- $\mathrm{Ni}$ is the area with variable $\mathrm{Xi}$.

- The $S$ is the total area with landslides belonging to the modeling group.

$-\mathrm{N}$ is the total area.

- The $\mathrm{S} / \mathrm{N}$ means a priori probability, the likelihood of each pixel to have a landslide without any consideration of predisposing factor.

- $\mathrm{Si} / \mathrm{Ni}$ is the conditional probability to have a landslide given the presence of variable $\mathrm{Xi}$.

The final susceptibility is then determined for each cell by the sum of the IV obtained for each one used as a conditioning factor (Equation 2).

$$
I V_{j}=\sum_{i=1}^{m} X_{i j} I_{i}
$$

Equation 2

Where,

- IVj is the total informative value of terrain $\mathrm{j}$,

- $m$ is a number of variables,

- Xij is either 0 if the variable is not present in the pixel $\mathrm{j}$, or 1 if the variable is present.

\subsection{Data}

In any slope instability analysis, a good knowledge of the mechanisms is required to identify the main factors for analysis. Landslide initiation is due to a variety of factors interacting in a complex way because the process happens continuously from cause to effect (Varnes, 1978)

There is a wide set of thematic data that could be used on the IVM for landslide susceptibility assessment in the study area. In this study, eight variables were 
considered as predisposing factors, which are mainly related to lithology, soil type, and morphology. Obtained either from existing maps or derived from DEM.
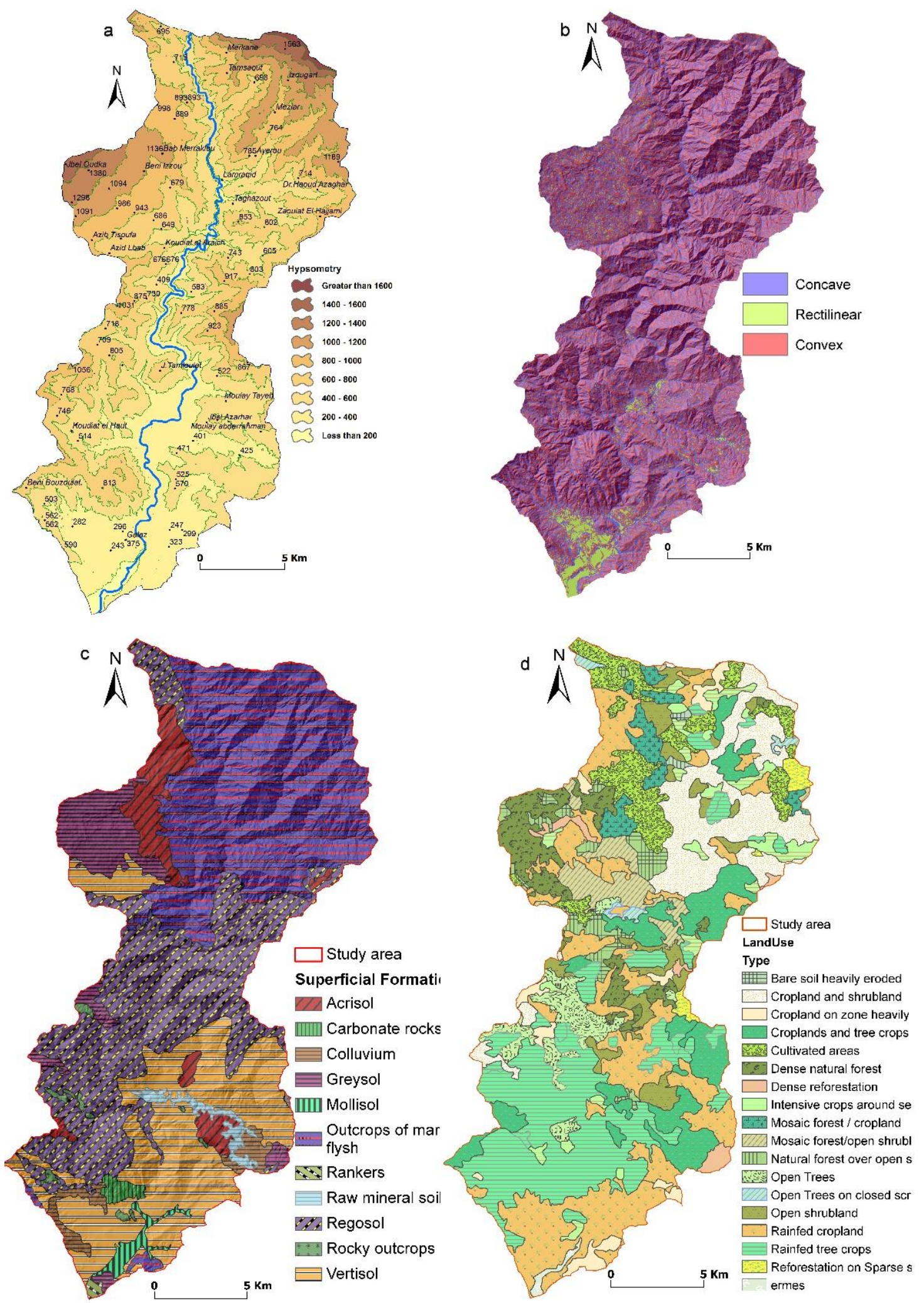

Figure 3a: Digital elevation model and the set of predisposing factors (a. DEM; b. Slope curvature; c. Superficial formations; $d$. land-use). 

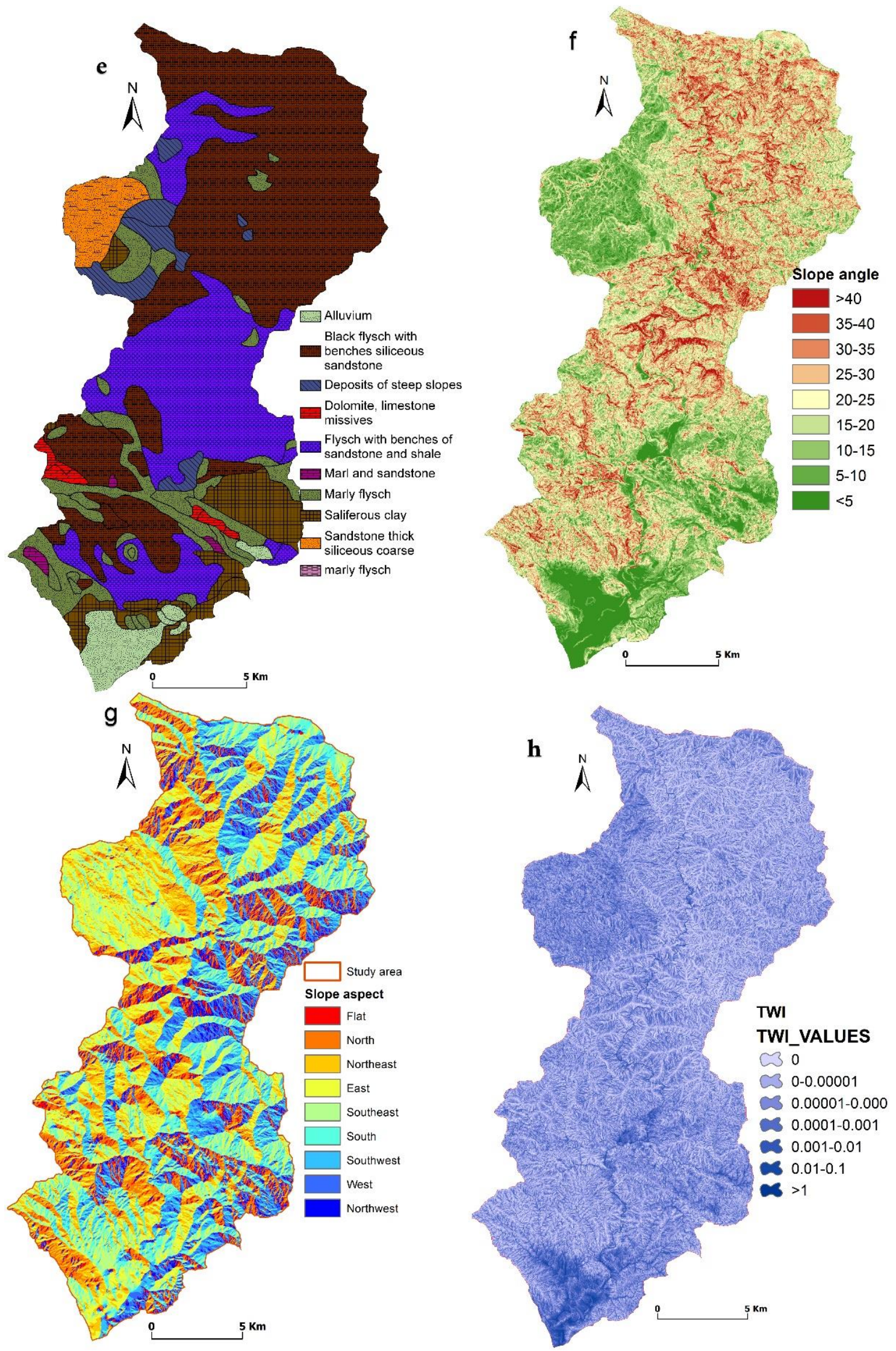

Figure 3b: Digital elevation model and the set of predisposing factors (e. Lithological formations; $f$. Slope angle; g. slope aspect; $h$. TWI). 


\subsubsection{Construction of Digital Elevation Model}

The digital elevation model (DEM) is a digital representation of the earth's topography which is presently used in several applications such as hydrology, geomorphology, geology, and risk mitigation. It is one of the most important imputes in modeling or simulating the landscape as well as dynamic natural phenomena such as flooding, soil erosion, and landslide (Wilson and Gallant, 2000). Due to the importance of DEM related to field work and applications, it is required to build a high-quality DEM to obtain a higher quality of models and its derivatives that come into account with the DEM.

To perform a detailed geomorphological analysis, a DEM $5 \mathrm{~m}$ pixel size of the study area was constructed (Figure 3.a). This model was generated from two types of data, contour lines and quoted points, altimetry data derived from the National Agency of Land Conservation, Land Registry and Mapping (ANCFCC) at 1:50 000 scales (contours with $10 \mathrm{~m}$ of interval and quoted points). DEM will be used for deriving several variables such as slope angle, slope aspect, and curvature.

\subsubsection{Lithology}

It is known that geological parameters largely influence the genesis of landslides because lithological and structural variations often lead to deference on strength and permeability of rocks and soils (Pradhan, Lee and Buchroithner, 2010). Among predisposing factors (such as slope angle, slope aspect, distance to streams and roads, land use, and land cover). The lithology concerning its type and mechanical characteristics plays a significant role in controlling the nature and rate of the geomorphological process taking place on the slopes (Figure 3.c).

Regarding landslide susceptibility mapping the geological parameters such as lithology and tectonic structures are important factors in landslide genesis because those variations usually contribute to different susceptibility to instability processes (Table I), resistance against weathering, and variation in geotechnical properties (Dai and Lee, 2002).

Table I: Areal distribution of lithological classes

\begin{tabular}{lrr}
\hline Lithological facies & Area $\left.\mathbf{( k m}^{2}\right)$ & Area (\%) \\
\hline Alluvium & 14.67 & 3.79 \\
Black flysch with benches siliceous sandstone & 168.94 & 43.65 \\
Deposits of steep slopes & 14.66 & 3.79 \\
Dolomite, limestone missives & 5.33 & 1.38 \\
Flysch with benches of sandstone and shale & 94.88 & 24.51 \\
Marl and sandstone & 1.73 & 0.45 \\
Marly flysch & 43.92 & 11.35 \\
Saliferous clay & 29.33 & 7.58 \\
Sandstone thick siliceous coarse & 13.56 & 3.50 \\
\hline SUM & $\mathbf{3 8 7 . 0 4}$ & $\mathbf{1 0 0}$ \\
\hline
\end{tabular}


Litho-stratigraphic demonstrates that black flysch with benches of siliceous sandstone (upper cretaceous) occupies $43.65 \%$ of the study area with $168.94 \mathrm{Km}^{2}$, especially on the northeast and southeast, while flysch with benches of sandstone and shale (Middle Cretaceous) occupies $24.51 \%$ with a total area of $94.88 \mathrm{Km}^{2}$, in addition to marly flysch and saliferous clay which occupies respectively $7.58 \%$ and $11.35 \%$. Sandstone thick siliceous coarse, marl and sandstone, deposits of steep slopes, and alluvium occupy all together $44.63 \mathrm{~km}^{2}$ of the surface area, it is a narrow area but important in explaining the occurrence of landslides in the area.

\subsubsection{Superficial formations}

Superficial materials (Figure 3.c) were mapped based on the soil map of Morocco (Coquant, 1996), ten classes were mapped and involved. However, various types of superficial deposits represent small areas and considering it's less important in slope instability in the study area, they were combined under one layer. The available data show the whole classes with their surface and characteristics (Table 2).

Table II: Soil types within the study area with their characteristics

\begin{tabular}{lrrl}
\hline Class & Area $\left.\mathbf{( K m}^{2}\right)$ & Area (\%) & Characteristics \\
\hline Rankers & 0.95 & 0.24 & Non-calcareous soils \\
Rocky outcrops & 2.28 & 0.59 & Rock material \\
Carbonate rocks & 2.34 & 0.60 & Sedimentary rocks \\
Mollisol & 3.53 & 0.92 & Rich in organic matter. \\
Raw mineral soil & 4.64 & 1.20 & Recent alluvium \\
Colluvium & 8.39 & 2.17 & sediments ranging from silt to \\
& & & rock fragments of various sizes \\
Acrisol & 20.81 & 5.39 & Clay-rich material \\
Gleysol & 23.50 & 6.09 & Unconsolidated materials \\
Vertisol & 82.84 & 21.48 & The high content of expansive \\
& & & clay \\
Regosol & 109.73 & 28.46 & Very shallow soil extensive in \\
& & & eroding lands \\
Outcrops of marl or flysch & 126.45 & 32.80 & Hilly relief consists of marl and \\
& & & flysch \\
\hline \hline SUM & $\mathbf{3 8 5 . 5 0 2 1}$ & $\mathbf{1 0 0}$ & \\
\hline
\end{tabular}

\subsubsection{Land use}

A permanent forest removal or destruction resulting from the planned conversion of forest to pasture, agriculture, possibly from continued shifting cultivation as practiced in many areas of Rif's chain, have influenced the stability of the hillslopes within the study area. Widespread conversion of forest and bushland to managed grassland has accelerated soil mass movement in both areas and numbers of soil slips due to the reduction in root reinforcement, consequence of root-wood deterioration, site disturbance, the introduction of different plant species, temporarily increasing water inputs and soil moisture related with the reduction of evapotranspiration. The influence of conversion and shifting forest to pasture or agriculture on slope stability depends on 
the density of residual trees and understory vegetation, rate, and type of regeneration, and site characteristics.

The high density of population and its growth in the area generate pressure on the food production and energy sources (i.e. firewood charcoal) which accelerates deforestation during the nineteenth century. In 1975 a survey carried out by the Hydrological Agency of Sebou Watershed (ABHS) showed a marked change in the way the land is used, demonstrating that between 1975 and 1996 most of the area was a forest with some areas of arable land along the main streams. From 1975 onward (Figure 3.d) the large swaths of the forest have been cleared for road and houses construction with intensive agriculture on steep slopes.

Tree crops, especially olive groves form the majority of the area with 7979 ha. The second-largest crop consisted of cereal crops, mainly wheat which is considered the most widely cultivated plant in the area, in addition to barely for feeding the livestock.

\subsection{DEM derivatives}

A large variety of DEM-derived elements can be calculated to model hydrogeomorphological processes, known as secondary topographic attributes according to Wilson and Gallant (2000). DEM derived variables (i.e. aspect, slope) have an important effect on a variety of ecological, hydrological, and morphological processes, Thereby the constructed DEM was used to derive the following variables, slope aspect, slope angle, curvature, and topographic wetness index.

\subsubsection{Slope orientation}

Slope orientation describes the direction in which a slope faces and relates to the degree of solar exposure. Aspect influences the vegetation found on the slope and the daily range of temperature and relative humidity. These environmental influences should be taken into account (Figure 3.g).

Incorporating the aspect among predisposing factors for landslides susceptibility assessment through the stability-based model makes much sense. Aspect is measured clockwise in degree from zero (due north) to 360 (again due north, coming full cycle). The number of each cell in the aspect grid gives the direction that the cell's slope faces. Flat slopes have no direction and are given a value of -1 (Green, 1988).

The areas of the slope orientation within Amzaz valley are nearly equal and (Table III). This factor could show important differences in terms of topo climatic characteristics of the drainage basin such as insolation, temperature, and soil moisture. 
Table III: Reclassified aspect map of the study area

\begin{tabular}{lcc}
\hline Class & \multicolumn{2}{c}{ Occupancy area } \\
\cline { 2 - 3 } & $\left(\mathrm{Km}^{2}\right)$ & $(\%)$ \\
North & 166.81 & 11.81 \\
northwest & 175.28 & 12.41 \\
East & 164.75 & 11.67 \\
Southeast & 180.13 & 12.75 \\
South & 199.1 & 14.10 \\
Southwest & 185.74 & 13.15 \\
West & 184.96 & 13.10 \\
Southwest & 185.74 & 13.15 \\
Northeast & 155.55 & 11.01 \\
\hline \hline SUM & $\mathbf{1 4 1 2 . 3 4}$ & $\mathbf{1 0 0}$ \\
\hline
\end{tabular}

\subsubsection{Slope gradient}

The slope is the gradient of the land surface. It is a crucial parameter in several wellknown predictive models used for environmental management, including the Universal Soil Loss Equation and landslide susceptibility assessment. There are several ways to express slope, whether as a percentage of slope angle, degree of slope, or radians (Dibiase and John, 2014). In this study, it was decided to classify the slope angle map into 8 classes using the degree $\left({ }^{\circ}\right)$ as a unit of measure (Figure 3.f).

A variety of authors and studies denote that there is a strong relationship between the angle of slope and the failure (Guzzetti, 2005). As the slope angle increases, the shear stress along with the slope increases due to added weight.

According to statistics of slope angle shown that $72.67 \%$ of the study area is dominated by slope angle between $20^{\circ}$ and $40^{\circ}$, thus the topography of the study area is characterized by steepness (Table IV).

Table IV: Reclassified slope angle map of the study area

Classes $\left(^{\circ}\right)$
Greater than $400^{\circ}$
$35-40$
$30-35$
$25-30$
$20-25$
$15-20$
$10-15$
$5-10$
Less than $5^{\circ}$
SUM

\begin{tabular}{cc}
\multicolumn{3}{c}{ Area } \\
\hline$\left(\mathrm{km}^{2}\right)$ & $(\%)$ \\
251.06 & 2.62 \\
551.00 & 5.75 \\
1047.64 & 10.93 \\
1420.91 & 14.83 \\
1546.71 & 16.14 \\
1501.16 & 15.67 \\
1375.19 & 14.35 \\
1137.31 & 11.87 \\
750.73 & 7.84 \\
$\mathbf{9 5 8 1 . 7 5}$ & $\mathbf{1 0 0 . 0 0}$
\end{tabular}

Guzzetti (2005) stated that there is a strong relationship between slope angle and landslide occurrence. Thus, relatively high values of slope angle, at least, up to a certain value, tend to be related to an increase in landslide occurrence. 


\subsubsection{Topographic wetness index}

The topographic wetness index (TWI) or compound topographic index (CTI) is a steady-state wetness index (Sørensen, Zinko and Seibert, 2006). It is mainly applied to the quantification of topographic control of hydrological processes. It is used to mark the distribution of soil moisture and surface saturation; it forms the key component of the distributed hydrological model. TWI is an important index for modeling the topography-related geographical processes at hillslope or watershed scale (Figure 3.h).

TWI combines local upland contributing area, slope, and a couple of geometric functions (Equation 3) developed by Beven and Kirkby (1979).

$$
\mathrm{TWI}=\ln \left(\frac{\mathrm{a}}{\operatorname{Tan}(\beta)}\right)
$$

Equation 3

Where,

- $a$ is contributing upland area $\left(\mathrm{m}^{2}\right)$ from flow accumulation raster,

- $\beta$ is the local slope angle (degree).

It is necessary to mention that the conversion from degrees to radians is compulsory because the calculation process with the degree in the GIS environment leads to problems that can be solved with radians.

The TWI has a higher value than the TWI of the nearing slope shoulder, which means that the terraces end toe slope areas have more potential to retain soil moisture than the nearby slope shoulders. The value of TWI reaches the highest in channels. This spatial distribution of TWI can scientifically indicate the spatial pattern of soil moisture. The first TWI class represents crests and ridges, whereas the last class represents drainage depressions.

Regarding the spatial distribution of water accumulation, it can be observed that TWI value increases due to the proximity of streams (TWI class $0.01-$ and $>0.1$ ), these places represent the permanent or temporary water sources where water accumulates. Whereas TWI classes $0.0001-0.001$ and $0-0.00001$ mostly represent steep slopes and ridges.

\subsubsection{Curvature}

The curvature of the slopes is the inverse of the radius of the circular tangent to the soil surface, hence, positive and negative curvature correspond respectively, to convergent and divergent topography and higher curvature correlate with stronger convergence (Figure 3.b). Concave slopes may retain too much water and not drain properly, whereas convex slopes may cause water to run off the slope causing water erosion processes. Concave shapes are represented in blue, convex shapes are in 
red and uniform shapes are in yellow. Curvature is also a way to measure the roughness of terrain. The roughness of a DTM surface is the ratio of surface (S) and its projection onto a horizontal plane (A) (Eric, Regis, 1989) (Equation 4).

$$
\text { Roughness }=\frac{\mathrm{S}}{\mathrm{A}}
$$

Equation 4

The curvatures map is classified into 3 classes and it expresses the variation between positive and negative values. A negative value indicates that the surface is upwardly convex at that cell, while a positive profile specifies that the surface is upwardly concave at that cell. Value around zero $(-0.05-0.05)$ indicates a linear slope (Zhou, Lees and Tang, 2008).

If a category is highly correlated to landslide, the area associated with this category will have a high positive IV. A negative IV for a specific category is an indicator of low landslide density in this class (Yin and Yan, 1988). Thus, for predisposing factors in landslide susceptibility mapping, its categories should provide a range of IV based on the combination of the spatial distribution of past mass movement with spatial patterns of the relevant conditioning factors of slope instability (Table V). The IV presents the relative susceptibility of the area unit to the occurrence of a particular type of landslides. Informative value for each type of mass movement was calculated separately.

Table V: Information values obtained for each class of each conditioning factor for each landslide type, significant values above zero are highlighted in bold.

\begin{tabular}{lrlcc}
\hline Predisposing factors & ID & Class & Rotational & Translational \\
\hline Lithology & 1 & Alluvium & -0.67 & -0.70 \\
\cline { 2 - 4 } & 2 & Black flysch with benches & 0.44 & 0.01 \\
& & siliceous sandstone & & \\
\hline 3 & Deposits of steep slopes & 0.49 & -0.70 \\
\hline 4 & Dolomite, limestone missives & 0.21 & -0.42 \\
\hline 5 & Flysch with benches of & -0.55 & 0.32 \\
& & sandstone and shale & \\
\hline 6 & Marl and sandstone & 0.84 & -0.70 \\
\hline 7 & Marly flysch & -0.61 & 0.40 \\
\hline Superficial & & Saliferous clay & -2.57 & -0.70 \\
formations & 9 & Sandstone thick siliceous coarse & -2.60 & -0.70 \\
& 1 & Acrisol & -1.61 & -1.05 \\
\hline 2 & Carbonate rocks & -2.32 & -2.87 \\
\hline 3 & Colluvium & -2.23 & -2.87 \\
\hline 4 & Greysol & -0.76 & -2.87 \\
\hline 5 & Mollisol & -2.32 & -2.87 \\
\hline 6 & Outcrops of marl or flysch & 0.71 & -0.22 \\
\hline 7 & Rankers & -2.32 & -2.87 \\
\hline 8 & Raw mineral soil & -0.11 & 0.66 \\
\hline 9 & Regosol & -0.24 & 0.36 \\
\hline 10 & Rocky outcrops & -2.32 & -2.87 \\
\hline 11 & Vertisol & -1.34 & 0.29 \\
\hline
\end{tabular}




\begin{tabular}{|c|c|c|c|c|}
\hline \multirow[t]{9}{*}{ Slope orientation } & 1 & North & 0.51 & -0.43 \\
\hline & 2 & Flat & -0.39 & 0.14 \\
\hline & 3 & Northeast & -0.26 & 0.08 \\
\hline & 4 & East & 0.59 & 0.39 \\
\hline & 5 & Southeast & -0.15 & -0.45 \\
\hline & 6 & South & -1.00 & 0.19 \\
\hline & 7 & Southwest & -0.29 & 0.13 \\
\hline & 8 & West & -0.80 & -0.42 \\
\hline & 9 & Northwest & 0.12 & -0.22 \\
\hline \multirow[t]{9}{*}{ Slope angle } & 1 & $>40$ & 0.51 & -0.43 \\
\hline & 2 & $35-40$ & -0.39 & 0.14 \\
\hline & 3 & $30-35$ & -0.26 & 0.08 \\
\hline & 4 & $25-30$ & 0.59 & 0.39 \\
\hline & 5 & $20-25$ & -0.15 & -0.45 \\
\hline & 6 & $15-20$ & -1.00 & 0.19 \\
\hline & 7 & $10-15$ & -0.29 & 0.13 \\
\hline & 8 & $5-10$ & -0.80 & -0.42 \\
\hline & 9 & $<5$ & 0.12 & -0.22 \\
\hline \multirow{7}{*}{$\begin{array}{l}\text { Topographic } \\
\text { wetness } \\
\text { index }\end{array}$} & 1 & 0 & 0.13 & 0.41 \\
\hline & 2 & $0-0.00001$ & -0.16 & -0.00 \\
\hline & 3 & $0.00001-0.0001$ & 0.06 & -0.11 \\
\hline & 4 & $0.0001-0.001$ & 0.14 & -0.37 \\
\hline & 5 & $0.001-0.01$ & -0.18 & -0.51 \\
\hline & 6 & $0.01-0.1$ & 0.08 & 0.49 \\
\hline & 7 & $>0.1$ & -0.85 & -0.57 \\
\hline \multirow[t]{3}{*}{ Curvature } & 1 & Concave slope & 0.11 & 0.19 \\
\hline & 2 & Rectilinear slope & -0.02 & -0.71 \\
\hline & 3 & Convex slope & -1.19 & -0.15 \\
\hline \multirow{18}{*}{ Land use } & 1 & Rainfed tree crops & -2.68 & -2.47 \\
\hline & 2 & Bare soil heavily eroded & -2.68 & -2.47 \\
\hline & 3 & Cropland and shrubland & 0.73 & -0.76 \\
\hline & 4 & $\begin{array}{l}\text { Cropland on zone heavily } \\
\text { eroded }\end{array}$ & 0.43 & -2.47 \\
\hline & 5 & Cropland and tree crops & 0.28 & 0.37 \\
\hline & 6 & Cultivated areas & 0.86 & -2.47 \\
\hline & 7 & Dese natural forest & -0.51 & -1.02 \\
\hline & 8 & Dense reforestation & -2.50 & -2.47 \\
\hline & 9 & Ermes & -2.68 & -2.47 \\
\hline & 10 & $\begin{array}{l}\text { Intensive crops around } \\
\text { settlements }\end{array}$ & -1.23 & -1.61 \\
\hline & 11 & Mosaic forest / cropland & 1.18 & 0.98 \\
\hline & 12 & Mosaic forest/open shrub land & -2.68 & 0.27 \\
\hline & 13 & $\begin{array}{l}\text { Natural forest over open } \\
\text { shrubland }\end{array}$ & 0.35 & -0.65 \\
\hline & 14 & Open shrub land & -0.28 & 0.33 \\
\hline & 15 & Open Trees & -2.68 & -0.55 \\
\hline & 16 & Open Trees on closed scrubland & -2.68 & -1.31 \\
\hline & 17 & Rainfed cropland & -0.73 & 0.01 \\
\hline & 18 & $\begin{array}{l}\text { Reforestation } \mathrm{n} \text { Sparse shrub } \\
\text { land }\end{array}$ & -0.52 & 0.54 \\
\hline
\end{tabular}

Regarding lithological classes for each landslide type, the flysch with benches of sandstone and shale followed by marly flysch is the lithological class more prone to shallow rotational slides. The flysch with benches of sandstone and shale class seemed to be the most unstable lithological class since it includes the majority of landslide occurrences. 
According to the IV, the marly flysch is very prone to rotational sliding. The area dominated by black flysch with benches siliceous sandstone is more prone to shallow translational slides (Figures 4 and 5).

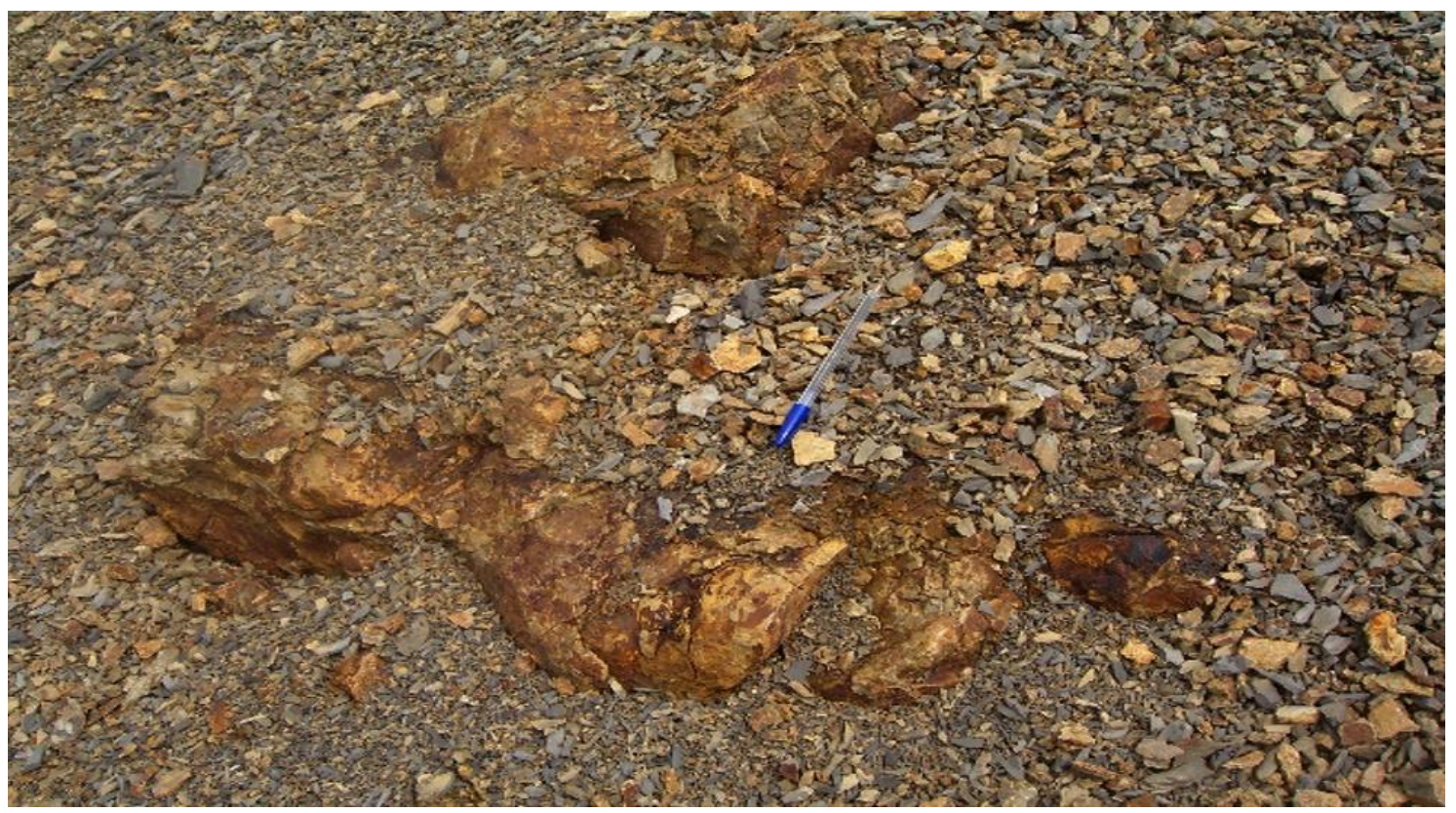

Figure 4: Presence of the flysch with benches of the sandstone formation with the dominance of the marl and sandstone in the Mestui village in NE of the Amzaz watershed.

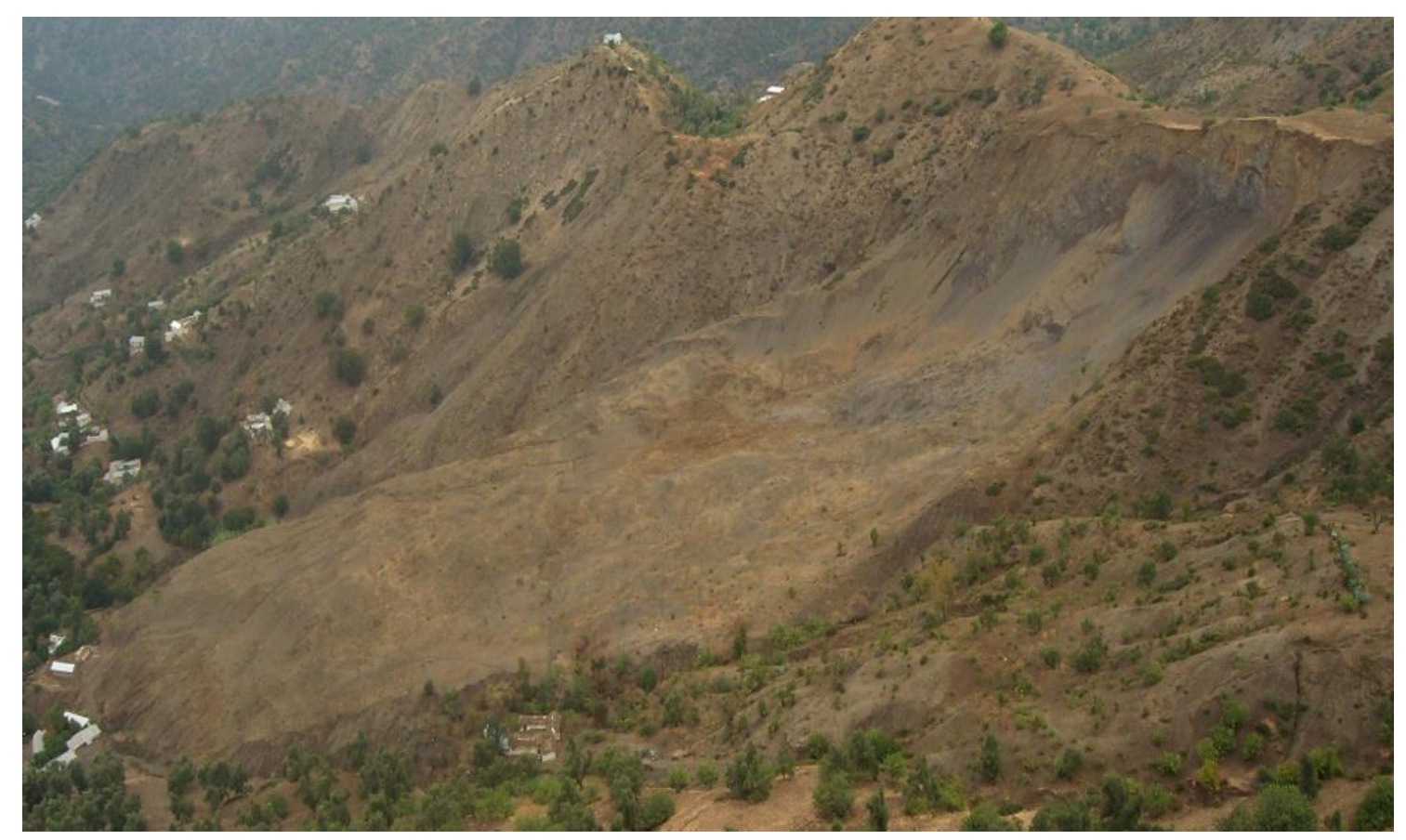

Figure 5: Rotational landslide in the Mestui village in NE of the Amzaz watershed. 
According to the slope angle, we can notice that classes between 25 to 40 degrees are more prone to shallow translational and rotational slides, whereas the other classes are stable according to their IV.

Once the informative values were calculated, were assigned to the respective classes of its respective variable, then summed using the raster calculator tool of ArcGis software. This procedure resulted in two maps of landslides susceptibility in Amzaz watershed, one for shallow translational slides susceptibility (Figure 6.a) and the other for shallow rotational slides susceptibility (Figure 6.b).

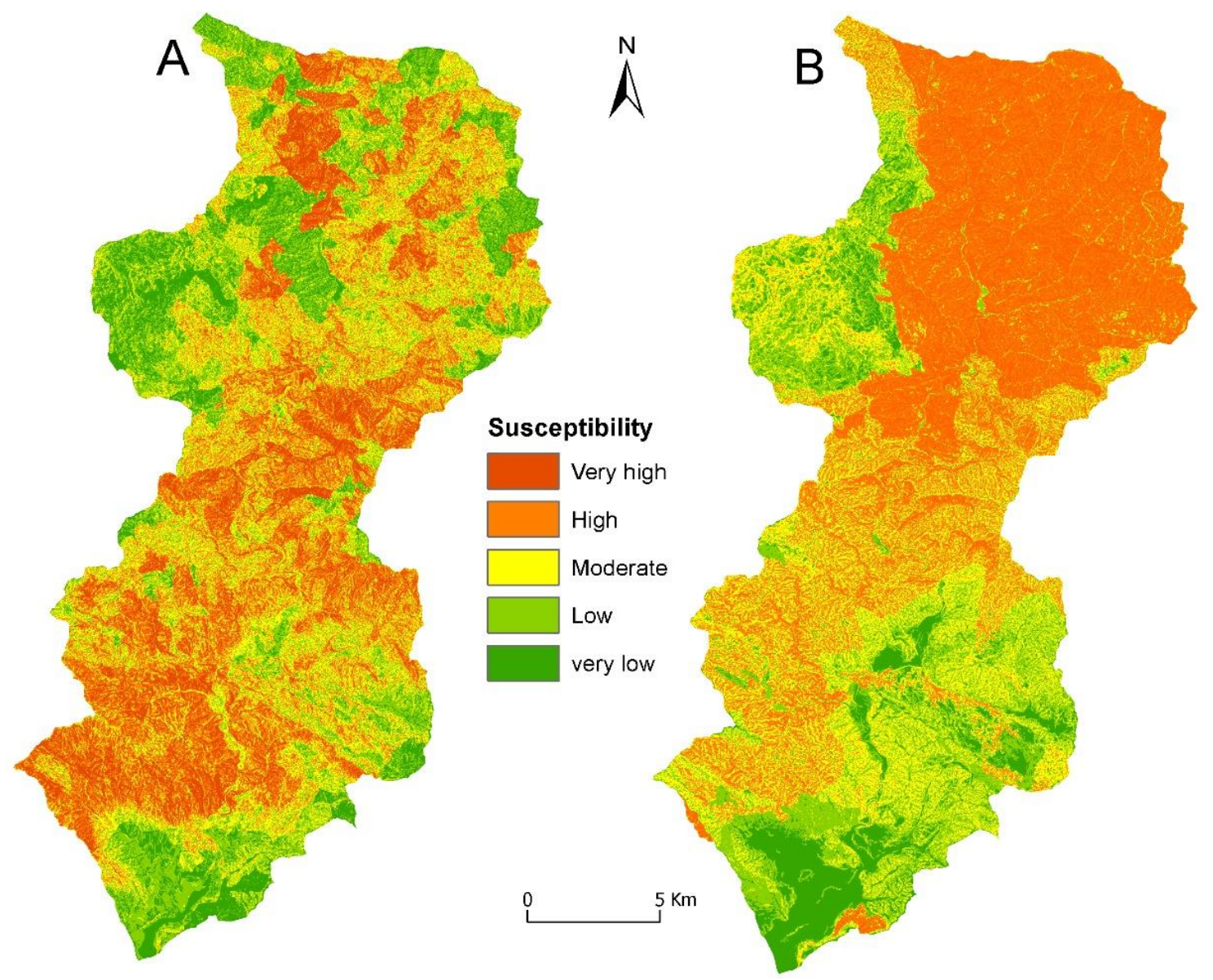

Figure 6: Shallow landslide susceptibility models assessed through IVM: a) translational; b) rotational.

The analysis of the landslide susceptibility maps concluded that there are two distinct parts in the study area. Generally, Figure 6 identifies the northeastern part of the study area as more susceptible to rotational landslides because most slopes are greater or equal to $20^{\circ}$ and the expansion of flysch and clayey formations lying upon an impermeable bedrock, whereas, the middle and southwest parts are more prone to translational landslides (Table VI). These parts of the study area are characterized by the presence of artificial cut (roads), and a moderate slope gradient that allows a gradual infiltration of water into the soil, which reduces the breaking capacity of the materials by increasing the pressure of the pore water. 
Table VI: Percentage of areas prone to landslide

\begin{tabular}{lcc} 
& \multicolumn{2}{c}{ Area (\%) } \\
\hline Susceptibility classes & Rotational & Translational \\
Very high & 18.40 & 13.36 \\
High & 30.08 & 29.58 \\
Moderate & 24.25 & 26.10 \\
Low & 18.48 & 21.18 \\
Very low & 8.79 & 9.79
\end{tabular}

\section{Conclusion}

Based on the analysis of the landslide susceptibility in the Amzaz watershed, the results demonstrated that there are two distinct parts in the study area. The northeaster area is more susceptible to rotational landslides because most of the slopes are greater or equal to $20^{\circ}$ and the expansion of flysch and clayey formations lying upon an impermeable bedrock, whereas, the middle and southwest parts are more prone to translational landslides. The south part is characterized by the presence of artificial cut (roads), and moderate slope gradient.

The Information Value generated based on the seven parameter maps range from 2.8762 to 0.9891 for translational slides and from 0.9198 to -2.6817 for rotational slides. The values were classified into four susceptibility classes (very low, low, moderate, high, and very high) by employing natural breaks method in ArcGis. The classification was done automatically under the ArcMap environment. The final results demonstrate where the percentage of areas classified as very low, low, moderate, high, very high susceptibilities are $8.79,18.48,24.25,30.08$, and $18.40 \%$ respectively for rotational slides, and for translational slides, the values are 9.79, 21.18, 26.10, 29.58 and 23.36 .

\section{Acknowledgment}

This paper is part of the thesis submitted by Mr. El-fengour Abdelhak, completed by the other authors within the ongoing project Reclimplan in the framework of Ibn Khaldoun program for scientific research, coordinated by the University Mohamed V in Rabat, Morocco.

\section{Bibliografia}

Beven, K., Kirkby, M. J. (1979). A physically based, variable contributing area model of basin hydrology/Un modèle à base physique de zone d'appel variable de l'hydrologie du bassin versant. Hydrological Sciences Journal, 24(1), 43-69. https://doi.org/10.1080/02626667909491834

Coquant, S. O. J. M. (Cartographer). (1996). Etude pedologique de reconnaissance au 1/100.000 en vue de la mise en valeur agricol dans les cercles de taounate et ghafsai, province de taounate. 
Dai, F. C., Lee, C. F. (2002). Landslide characteristics and slope instability modeling using GIS, Lantau Island, Hong Kong. Geomorphology, 42(3), 213-228. https://doi.org/10.1016/S0169-555X(01)00087-3

Dibiase, D., John, A. D. (2014). The Nature of Geographic Information. United States: The Pennsylvania State University.

Eric, K., Regis, H. (1989). Terrain Roughness. SPIE, 1195 (Mobile Robots IV).

Green, N. (1988). Principles of geographical information systems for land resources assessment. Publisher Oxford University press.

Guzzetti, F. (2005). Landslide hazard and risk assessment: concepts, methods and tools for the detection and mapping of landslides, for landslide susceptibility zonation and hazard assessment, and for landslide risk evaluation, Perugia, Italy. (PhD). MathematichNaturwissenschaftlichen Fakultät, Rheinischen Friedrich-Wilhelms-Univestität Bonn, Bonn, Germany.

Pradhan, B., Lee, S., Buchroithner, M. F. (2010). Remote sensing and GIS-based landslide susceptibility analysis and its cross-validation in three test areas using a frequency ratio model. Photogrammetrie-Fernerkundung-Geoinformation, 2010(1), 17-32. https://doi.org/10.1038/srep09899

Soeters, R., Westen, V. (1996). Slope instability recognition, analysis and zonation. In K. Turner \& R. Schuster (Eds.), Landslides investigation and mitigation (pp. 129-177). Washington: National Academy Press.

Sørensen, R., Zinko, U., Seibert, J. (2006). On the calculation of the topographic wetness index: evaluation of different methods based on field observations. Hydrology and Earth System Sciences, 10, 101-112. https://doi.org/10.5194/hess-10-101-2006

Van Westen, C. J. (1994). GIS in Landslide Hazard Zonation: A Review, with Examples from the Colombian Andes. In D. I. Heywood (Ed.), Mountain Environments and Geographic Information Systems (Vol. 1, pp. 135-165.). London: Taylor and Francis.

Varnes, D. J. (1978). Slope movement types and processes (0360-859X). Washington D. C.

Wilson, J. P., Gallant, J. C. (2000). Terrain Analysis: Principles and applications. New York, NY.: Wiley.

Yin, K. L., Yan, T. Z. (1988, 1988). Statistical prediction model for slope instability of metamorphosed rocks. Paper presented at the Proceedings of the 5th international symposium on landslides, Lausanne, Switzerland.

Zhou, Q., Lees, B., Tang, G. A. (Eds.). (2008). Advances in digital terrain analysis. Berlin/Heidelberg, Germany: Springer.

Artigo recebido em / Received on: 07/10/2020

Artigo aceite para publicação em / Accepted for publication on: 02/12/2020 
El-fengour et al. / Physis Terrae, Vol. 2, no 2, 2020, 3-19

Página intencionalmente deixada em branco 